\title{
Brazilian scientific production on pharmaceutical care from 1990 to 2009
}

\author{
Maria Denise Ricetto Funchal-Witzel ${ }^{1, *}$, Lia Lusitana Cardozo de Castro², Nicolina Silvana \\ Romano-Lieber ${ }^{3}$, Paulo Capel Narvai ${ }^{4}$
}

\begin{abstract}
Department of Public Health Practices, Faculty of Public Health, University of São Paulo, ${ }^{2}$ Brazilian Society of Drug Vigilance, Directive Council, ${ }^{3}$ Department of Public Health Practices, Faculty of Public Health, University of São Paulo, ${ }^{4}$ Department of Public Health Practices, Faculty of Public Health, University of São Paulo
\end{abstract}

\begin{abstract}
Brazilian scientific production on pharmaceutical care was identified based on articles indexed on the Medline, Embase, Lilacs, Web of Science and International Pharmaceutical Abstracts databases. Sixtythree articles published in both national and international journals were retrieved. With regard to authors, $72.3 \%$ were from the Southeast and South Regions, and $60.8 \%$ were affiliated to public universities. In relation to the type of studies, $85.7 \%$ were descriptive, and the most frequently researched fields were community pharmacies, hospitals and primary health care units. Articles were original in $65.1 \%$ of cases, updates in $20.6 \%$, and reviews in $7.9 \%$. An increase in publications commenced in 2006 . In $31.7 \%$ of cases, authors had adopted a bibliographical study design, $28.6 \%$ qualitative study, $23.8 \%$ intervention, and $15.9 \%$ observational study design. The most researched subjects were elderly with chronic diseases. The importance of stimulating the conducting of experimental and qualitative studies, as well as amplifying authorship affiliated with the service area, foreign authors and with research in a wide variety of practice settings were highlighted. Despite the limited quantity of articles, an increase in their number as well as in their scope and quality is expected, so as to create further knowledge that contributes to the recognition of pharmacists' actions by patient healthcare teams.
\end{abstract}

Uniterms: Pharmaceutical care. Pharmaceutical assistance. Public health. Pharmaceutical services.

Identificam-se características da produção científica brasileira sobre atenção farmacêutica, a partir de artigos indexados nas bases Medline, Embase, Lilacs, Web of Science e International Pharmaceutical Abstracts. Foram localizados 63 artigos em revistas nacionais e internacionais. Em relação aos autores, $72,3 \%$ pertenciam as Regiões Sudeste e Sul e $60,8 \%$ estavam vinculados a universidades públicas. Quanto ao tipo de pesquisa, $85,7 \%$ foram descritivas, sendo campos mais pesquisados: farmácias comunitárias, hospitais e unidades básicas de saúde. Os artigos foram considerados originais $(65,1 \%)$, atualizações $(20,6 \%)$ e revisões $(7,9 \%)$. O aumento das publicações se deu a partir de 2006 . Em 31,7\% dos casos os autores optaram por estudo bibliográfico, $28,6 \%$ qualitativo, $23,8 \%$ de intervenção e $15,9 \%$ observacional. Os principais sujeitos pesquisados foram idosos com enfermidades crônicas. Aponta-se a importância de estimular a realização de estudos experimentais e qualitativos, ampliar a autoria vinculada à área de serviços, o vínculo com autores estrangeiros e a pesquisa em todos os ambientes de prática. Apesar da quantidade limitada de artigos espera-se aumento de seu número, abrangência e qualidade de forma a gerar conhecimento que contribua para o reconhecimento das ações do farmacêutico na equipe de atenção ao paciente.

Unitermos: Atenção Farmacêutica. Assistência Farmacêutica. Saúde pública. Serviços Farmacêuticos.

\footnotetext{
*Correspondence: M. D. R. Funchal-Witzel, Faculdade de Saúde Pública, Universidade de São Paulo, Avenida Dr. Arnaldo, 715, 01246-904 - São Paulo

- SP, Brasil. E-mail: dfunchal@terra.com.br
} 


\section{INTRODUCTION}

The transformation in health technologies and systems that occurred during the 20th Century has changed both health concepts and the users' needs and expectations about medical services. This shift in perception calls into question the traditional functions and responsibilities of healthcare professionals with regard to their ability to cope with the complexity of health problems in society (Cipolle, Strand, Morley, 2000; Martinez Olmos, Baena Parejo, 2001).

The pharmacist's role and functions have become the focus of intense debate, and are undergoing significant transformation, especially in the United States and Europe (Hepler, Strand, 1990; Penna, 1990; Hepler, GraigerRousseaux, 1995; Faus Dáder, Martinez Martinez, 1999; Cipolle, Strand, Morley, 2000; OPAS, 2004). This has also had repercussions in Latin America, with a trend toward strengthening the performance of these professionals in relation to service rendered to their patients (OPAS, 2002).

Although medicines are used in order to resolve health problems, they can also cause harm and, if not identified or treated early, can lead to morbidity or even death (Bootman et al., 1997). Studies have described the adverse results of pharmacotherapy that contribute to, or directly cause, the need for additional care including medical appointments, visits to the emergency ward, hospital admissions, and increasing time and complexity of hospitalization (Hepler, Graiger-Rousseaux, 1995; Tuneu Vaus et al., 2000; Martinez Olmos, Baena Parejo, 2001; Dall'Agnos et al., 2004; Campos Vieira, 2004; Silva Castro, 2004; Baena Parejo et al., 2005).

In 1990, Hepler and Strand carried out an extensive review of the pharmaceutical profession and investigated the opportunity pharmacists have to effectively contribute to the safety and effectiveness of pharmacotherapy by means of the pharmaceutical care practice. These authors proposed a concept for pharmaceutical care which, after its spread all over the world, has created healthcare assistance practice models adapted to the specific peculiarities of each country, with a view to minimizing health problems related to medicines.

In Brazil, pharmaceutical care has become the focus of discussions among researchers, policy makers as well as pharmacists (OPAS, 2002). However, what are the repercussions of these discussions on the Brazilian researchers' scientific production in the pharmaceutical area?

The aim of this article was to describe the characteristics of Brazilian scientific production on pharmaceutical care published in indexed journals with the purpose of contributing to the broadening of knowledge on its relevant aspects, as well as verifying its evolution over time while identifying gaps that might be the focus of future research.

\section{METHODS}

This analysis of scientific production on pharmaceutical care has been carried out based on the selection of articles published by Brazilian authors in journals indexed on the Medline, Embase, Lilacs, Web of Science and International Pharmaceutical Abstracts (IPHA) databases, between 1990 and 2009. The landmark from which the pharmaceutical care theme gradually started being discussed and adopted by several countries, including Brazil, is considered to be 1990 (Funchal-Witzel, 2008).

The decision to elect published articles as an indicator of scientific production is due to the fact that scientific journals have been playing a fundamental role in disseminating knowledge. A quality scientific article is expected to be published in a quality journal, and this journal is indexed on the best database of its area, thus meeting the researchers' needs for information, who in turn are also authors. This information flow makes research a constant producer and also consumer of information (Curty, Boccato, 2005).

As a search strategy, the use of a combination of key-words and subject descriptors was adopted, taking the controlled vocabulary of each database into consideration. Thus, the retrieval of articles was done through the combination of the terms "pharmaceutical care", "pharmaceutical services", "pharmaceutical assistance" and "Brazil", anywhere in the text, as subject descriptors or free words, depending on the characteristics of the database in question.

Articles referring to pharmaceutical care in the context of pharmaceutical services rendered to patients, according to the Brazilian proposal of pharmaceutical care consensus (OPAS, 2002), were considered as the inclusion criteria. Articles that merely quoted pharmaceutical care without any relation to the rendering of services to patients were excluded. Editorials, notes, opinions, summaries of conferences and congresses, and other text formats that were not presented with the clearly defined pre-textual, textual and post-textual elements were also excluded from this analysis.

The articles retrieved were subjected to evaluation of duplicity, then to exploratory, analytical and interpretative reading processed, followed by a classification proposed by Gil (1995). In order to record data, a collection record was devised, divided into four main blocks: authors, research, article and studied population. 


\section{RESULTS AND DISCUSSION}

Out of the 440 publications retrieved, after exclusion of repeated records, 63 articles from Brazilian authors published in 26 national and international journals addressing the pharmaceutical care issue were selected. In comparison, Andrés Iglesias, Andrés Rodriguez and Fornos Perez (2007), in a bibliometric study on the publications about pharmaceutical care in a Spanish community pharmacy from 1995 to 2005, recovered 491 articles contained on the databases researched by them, but only $26(5.3 \%)$ met the inclusion criteria established in their study. This was a lower percentage than that found in the present study, whose final articles represented $14.3 \%$ of the total articles retrieved. However, when conducting a direct search of two Spanish journals that dealt with the theme, the authors increased the number of recovered publications to 122 .

One verified difficulty regarding the retrieval of articles on the theme was the lack of uniformity of terms and concepts assigned to the subject descriptors and to the key-words across different databases. In addition, it was also necessary to consider the alterations in this vocabulary with time. Thus, on the Lilacs database, up to 2009, the subject descriptors 'pharmaceutical assistance and care' were considered synonyms and had a broad scope, being more related to aspects of public policies rather than to the individual attendance of the user of medicines, whereas the subject descriptor "pharmaceutical services" was closer to the concept of pharmaceutical care. As of 2009, "pharmaceutical care' and 'pharmaceutical assistance' have no longer been synonyms, for the first term has assumed the concept focused on the attendance of the user of medicines, while the second one takes on a more comprehensive character, being a synonym of "pharmaceutical assistance services'. The term "pharmaceutical services" however, has been abolished from the vocabulary controlled by the database. 'Pharmaceutical care' is not considered a subject descriptor on the Medline or Embase databases, and the 'pharmaceutical services' subject descriptor is more related to the concept of pharmaceutical care. On the IPHA database, 'pharmaceutical care' is a subject descriptor. The Web of Science database does not offer the subject descriptor field for searches which requires the use of combined words. These factors led to the need of using search strategies combining both subject descriptors and key-words, with the aim of retrieving articles that are a closer match to the research object. Despite this, a substantial number of articles unrelated to the theme were retrieved.

Another difficulty was related to the use of the terms 'assistance' and 'care' within the context of pharmacy. Within the public health scope, the term 'care' is considered to be comprehensive, for it includes individual assistance without exhausting its meaning, whereas the term 'assistance' refers to the set of procedures individually targeted to the users of health services (Narvai, Frazão, 2008). In the context of pharmacy, these terms have the opposite meanings, since pharmaceutical assistance is considered to be the broadest term, in which the term "care" is implied, corresponding to the activities of pharmacists addressed to the user of medicines on an individual basis. This terminology issue warrants deeper discussion, for it may compromise the quality of communication among pharmacists and non-pharmacists.

Oshiro and Castro (2008), upon reviewing the Brazilian publications about pharmaceutical care from 1999 to 2005 in journals, congress annals, governmental texts and isolated publications (dissertations, theses, books and others), selected 307 publications, 99 of which were articles published in journals, and 4 in journals indexed on the Lilacs database. In the present study, considering the same time period (1999-2005), 12 articles published in indexed journals were recovered. This means that despite the difficulties of the searches, it was possible to increase the retrieval of articles by performing the search on a broader number of databases, and by using the combination of descriptor and key-word strategy. It is important to highlight that the number of publications about pharmaceutical care is low in biomedical journals (Rangel Mayoral, Luis Fernandez, Liso Rúbio, 2005). Therefore, a significant part of this production is not made available to the scientific community in general.

Out of the 26 identified journals, $38.5 \%$ were related to the pharmaceutical sciences area, $23.1 \%$ to the medical sciences, $19.2 \%$ to public health, $7.7 \%$ to pharmacotherapy, $7.7 \%$ to health education, and $3.8 \%$ to biological and health sciences. Although the journals related to the pharmaceutical area prevailed, the publications were not restricted to them, since $61.5 \%$ of the articles were published in journals pertaining to other areas.

\section{The authors}

One hundred sixty-six authors were registered, although this figure did not correspond to the total number of authors, because only the first two and the last author were considered. It was not possible to identify the title of $74.7 \%$ of the authors. Among those identified, $10.2 \%$ were doctors, 5.4\% Masters or specialists, and 5.4\% Full Professors, PhDs or Associate Professors. A larger percentage of female authors was observed compared to male authors, and a higher number of professors (Full Professors, $\mathrm{PhDs}$ or Associate Professors) and doctors were found 
among the male authors in comparison to female authors. However, in $16.3 \%$ of the cases, it was not possible to deduce sex based on the authors' names in the publications (Table I).

With regard to the institutional origin, $60.8 \%$ of the authors registered their affiliation to public universities, $13.8 \%$ to private universities, and $12.0 \%$ to health services, of whom $8.4 \%$ were affiliated with public services, and $3.6 \%$ to private services. Also, $6.0 \%$ of authors were affiliated with foreign institutions (Table II).

It has been observed that, despite the fact that pharmaceutical care is a professional practice concept developed for the service settings, few authors were affiliated with this environment. This finding may be related to aspects of the service itself or to health service studies.

Regarding the first issue, it is known that: a) most administrators do not acknowledge the importance of the pharmacy services, which results in inadequate physical infrastructure as well as human resources; b) there is an absence of adequate pharmaceutical services that act in an articulated fashion with other professional services; c) there is an absence of acting pharmacists (understaffing) or shortage of professionals in the service areas (Vieira, 2007). These situations make it difficult for the service pharmacists to engage in research activities.

Concerning health service studies, Novaes (2004) reported that although services is the setting in which the professionals and the technologies responsible for health

TABLE I - Academic titles of authors who published articles about pharmaceutical care in journals indexed on databases, according to sex. Brazil, 1990-2009

\begin{tabular}{lcccccccc}
\hline \multirow{2}{*}{ Academic Title } & \multicolumn{3}{c}{ Sex } & \multicolumn{3}{c}{ Total } \\
\hline Full professor/Associate $/ \mathrm{PhD}$ & 5 & 8.7 & 3 & 3.8 & 1 & 3.7 & 9 & 5.4 \\
Doctor & 11 & 18.0 & 6 & 7.7 & - & - & 17 & 10.2 \\
Masters/Specialist & 4 & 6.6 & 4 & 5.1 & 1 & 3.7 & 9 & 5.4 \\
Graduated & - & - & 4 & 5.1 & - & - & 4 & 2.4 \\
Academic student & 2 & 3.3 & 1 & 1.3 & - & - & 3 & 1.8 \\
Ignored & 39 & 63.9 & 60 & 76.9 & 25 & 92.6 & 124 & 74.7 \\
Total & 61 & 36.7 & 78 & 47.0 & 27 & 16.3 & 166 & 100.0 \\
\hline
\end{tabular}

TABLE II - Authors who published articles about pharmaceutical care in journals indexed on databases, by geographical area and institutional affiliation. Brazil, 1990-2009

\begin{tabular}{|c|c|c|c|c|c|c|c|c|c|c|c|c|c|c|c|c|c|c|c|}
\hline \multirow[b]{2}{*}{ Institutional Affiliation } & \multicolumn{17}{|c|}{ Author Geographical Origin } & \multicolumn{2}{|c|}{ TOTAL } \\
\hline & \multicolumn{2}{|c|}{$\begin{array}{l}\text { Midwest } \\
\text { Region }\end{array}$} & \multicolumn{6}{|c|}{$\begin{array}{l}\text { Northeast } \\
\text { Region }\end{array}$} & \multicolumn{4}{|c|}{$\begin{array}{l}\text { Southeast } \\
\text { Region }\end{array}$} & \multicolumn{3}{|c|}{$\begin{array}{l}\text { South } \\
\text { Region }\end{array}$} & EX & NI & $\mathrm{N}$ & $\%$ \\
\hline Public University & 6 & - & 1 & 4 & 2 & 5 & 2 & 3 & 1 & 18 & 2 & 24 & 21 & 6 & 6 & - & - & 101 & 60.8 \\
\hline Private University & - & - & - & 1 & - & - & - & 1 & 1 & 3 & - & 6 & 3 & - & 8 & - & - & 23 & 13.8 \\
\hline Private Health Service & - & - & - & - & 1 & - & - & - & - & 2 & - & - & 3 & - & - & - & - & 6 & 3.6 \\
\hline Public Research Institute & - & 1 & - & - & - & - & - & - & - & - & 2 & - & - & - & - & - & - & 3 & 1.8 \\
\hline Foreign Institution & - & - & - & - & - & - & - & - & - & - & - & - & - & - & - & 10 & - & 10 & 6.0 \\
\hline More than one institution & & - & - & 1 & - & - & - & - & 2 & - & 2 & - & - & - & - & - & - & 5 & 3.0 \\
\hline Not Identified & - & - & - & - & - & - & - & - & - & - & - & - & - & 1 & - & - & 3 & 4 & 2.4 \\
\hline
\end{tabular}

DF - Distrito Federal; MS - Mato Grosso do Sul; BA - Bahia; CE - Ceará; PB - Paraíba; PE - Pernambuco; PI - Piauí; SE - Sergipe;

ES - Espírito Santo; MG - Minas Gerais; RJ - Rio de Janeiro; SP - São Paulo; PR - Paraná; RS - Rio Grande do Sul; SC- Santa Catarina;

EX - Exterior/Overseas; NI - Not Identified 
care are deployed, studies on this environment remain scarce in Brazil. Moreover, despite the fact that many assignments contribute to knowledge in the service area, the fact is that studies related to medicine, nursing, epidemiology, technological and economic evaluation, public health, management and administration, as well as social and political sciences tend to dominate. Thus, it seems that the pharmaceutical area is not traditionally involved with this kind of research.

With regard to geographical origin, $18.7 \%$ of the authors were affiliated with the State of São Paulo, 16.3\% to Paraná, $13.8 \%$ to Minas Gerais, $9.0 \%$ to Santa Catarina, $8.4 \%$ to Rio Grande do Sul and $6.0 \%$ to the Federal District (Table 2). Therefore, authors affiliated with the Southeast and South regions were those who most published, and were responsible as a group for $72.2 \%$ of the publications. When Mugnaine, Jannuzzi and Quonian (2004) evaluated the technological and scientific production of the Brazilian research institutions during the nineties, they verified a significant increase in academic output and, although the research continues to be strongly concentrated in the States of São Paulo and Rio de Janeiro, the participation of researchers from other States has been increasing, especially from Minas Gerais. It is important to highlight that at the $2^{\mathrm{a}}$ Conferência Nacional de Ciência, Tecnologia e Inovação em Saúde ( $2^{\text {nd }}$ National Conference on Science, Technology and Health Innovation) held in 2004, pharmaceutical care had been included as a research theme in the Agenda Nacional de Prioridades de Pesquisa em Saúde (National Agenda on Health Research Priorities). As a result, an edict was published, which has opened doors to the fostering of research about pharmaceutical care nationwide. It is hoped that this may contribute to the decentralization of research on this theme (Brasil, 2006).

The internationalization of Brazilian scientific production is another aspect to be taken into consideration. In the present survey, $6.0 \%$ of the authors were from overseas, that is, 1 from Qatar, 2 from the United States, 3 from Spain, 3 from Canada and 1 from Cuba. Mugnaine, Jannuzzi and Quonian (2004) highlighted the increase in collaborative partnerships of Brazilian authors with researchers from the United States, Europe and South America regarding all areas. The findings of the current study corroborated this tendency, and it is believed that this trend is set to increase in the near future, for the participation of Brazilians on post-graduate courses in the pharmaceutical care area abroad has become more frequent.

The authors' electronic addresses were present in $90.5 \%$ of the articles. Coimbra Jr (1999) highlights that this finding is important, for when the reader is interested in a certain theme and finds the author's electronic address, they are able to contact the author to exchange information, which thus contributes to the interchange and evololution of knowledge. The absence of this contact information however, compromises this process.

\section{The studies}

Descriptive studies prevailed, accounting for $85.7 \%$ of the work retrieved. Analytical research testing "cause and effect" as well as that testing association, corresponded to $9.5 \%$ and $4.8 \%$ of the total, respectively. This reveals a lack of analytical studies, particularly controlled and randomized experimental studies. According to Andrés Iglesias, Andrés Rodríguez and Fornos Pérez (2007) this finding seems to be common to studies related to the pharmaceutical care area. A lack of qualitative studies involving social and human science references has also been noted, a topic identified in only $11.1 \%$ of the retrieved articles.

Two methodologically complex studies among the analyzed scientific production are noteworthy: a metaanalysis about the pharmaceutical interventions in the handling of hypertension, and a meta-synthesis on the meaning of pharmacotherapy to the patient, both performed by Brazilian authors in partnership with foreigner authors (Machado et al., 2007; Shoemaker, Oliveira, 2008). Studies that demand more complex methodological designs such as those cited are, for the most part, developed as Master dissertations or doctorate theses. Only $3(4.8 \%)$ articles identified in the text body that the studies in question were related to post-graduate studies. However, when searching the name of the first author on the database of theses from the Coordenação de Aperfeiçoamento de Pessoal de Nível Superior (CAPES / Agency for the Development of Higher Education Personnel), 17 articles (27.0\%) were related to theses or dissertations. Therefore, reference to this alternative source has proven more effective for the obtention of this kind of information than by searching for this information in the articles, since not every editor requests the authors to identify the academic motives behind submission of the article for publication.

The source of funding and resources employed to carry out the published studies was unavailable for $80.9 \%$ of the articles. Narvai and Almeida (1998), on evaluating the Brazilian publications related to the prevention and social dentistry area, faced a similar situation, and highlighted the importance of performing further investigation to ascertain the implications of this finding.

Out of the 12 articles (19.0\%) that identified the source of resources, $58.3 \%$ had multiple financial sources. The financial sources mentioned were: Fundações 
de Amparo a Pesquisa dos Estados (FAP / Foundations to the Fostering of Researches within each state), Conselho Nacional de Desenvolvimento Científico e Tecnológico (CNPq / National Committee for the Scientific and Technological Development), Coordenação de Aperfeiçoamento de Pessoal de Nível Superior (CAPES / Agency for the Development of Higher Education Personnel), Ministério da Saúde (MS / Health Ministry), Universidade Estadual de Campinas (UNICAMP / State University of Campinas), Universidade de Vila Velha (Vila Velha University), Instituto Ethosfarma (Ethosfarma Institute), and foreign institutions.

Despite the fact that $18.7 \%$ of the authorships were related to the State of São Paulo, Fundação de Amparo a Pesquisa do Estado de São Paulo (FAPESP) was mentioned in just 3 articles, one of which was by authors from the State of Paraná. Therefore, FAPESP seems to have financed only two studies from authors based in the State of São Paulo. This finding shows that, regarding the State of São Paulo, either the state financing agency has not recognized the importance of the theme, or the authors of the studies have not been submitting their projects to this research funding agency.

In $63.5 \%$ of the articles, the study venue (field) was identified because it is relevant to the research (Table III). The principal fields researched were found to be: community pharmacy, hospital pharmacy/hospital services, and primary health care units/health center, each representing $22.5 \%$ of the study venues, followed by school-pharmacy with $12.5 \%$, and domicile that corresponded to $7.5 \%$. The fields of long-term institutions and patients' associations were associated to one article each.

Andrés Iglesias, Andrés Rodríguez and Fornos Perez (2007) found 122 articles related to pharmaceutical care in
Spanish community pharmacies from 1995 to 2005 (average of 11.1 articles per year), which they considered a low output compared to those performed within the hospital pharmacy setting. Nevertheless, they highlighted that this number is close to the figures for countries like Canada, for instance. In Brazil, for the same period spanning from 1995 to 2005,3 publications on community pharmacy were retrieved out of the 9 studies published from 1990 to 2009. This finding shows that the Brazilian scientific output in this field is low and below the country's potential, given that this practice could be more consolidated in this environment.

Regarding the hospital pharmacy, Margarinos-Torres, Osório-de-Castro and Pepe (2007) highlighted that there is still a scarcity of literature related to Brazilian studies on pharmacotherapeutic follow-up of hospitalized patients. This lack of studies may be explained by the fact that hospital pharmacies have, in general, major structural problems related to management, screening and logistics, such as: a) planning regarding the purchase of products; $b$ ) standardization of drugs; c) qualification process of suppliers; d) recording of stock movement; e) storage conditions; f) disposal of expired products; g) definition of weaknesses in the process of distribution and dispensing, among others, that need to be dealt with before pharmacotherapeutic follow-up studies are accomplished on a larger scale.

The Basic Health Care Unit, which is the main point of entry to the Brazilian health system, remains a little studied field. In these units, structural problems are evident that make the interaction between the pharmacists and the user difficult, such as: a) insufficient physical space for the storage of drugs and patient care area; b) inappropriate location for drug dispensing; c) lack of pharmacists during the whole operation period of the unit. Furthermore, in

TABLE III - Locate of data collection and study setting of articles on pharmaceutical care. Brazil, 1990-2009

\begin{tabular}{|c|c|c|c|c|c|c|c|c|c|c|c|c|c|c|c|}
\hline \multirow[t]{2}{*}{ Study setting } & \multicolumn{13}{|c|}{ Locale of data collection } & \multicolumn{2}{|c|}{ TOTAL } \\
\hline & $\mathrm{CE}$ & ES & $\mathrm{MG}$ & MS & PE & PB & PR & RJ & $\mathrm{RS}$ & $\mathrm{SC}$ & SP & EX & $\mathrm{NI}$ & $\mathrm{N}$ & $\%$ \\
\hline Community pharmacy & - & - & 1 & 1 & - & 1 & 4 & - & - & 1 & 1 & - & - & 9 & 22.5 \\
\hline Hospital Pharmacy /HS & 1 & - & - & - & - & - & - & 1 & 2 & 1 & 2 & 1 & 1 & 9 & 22.5 \\
\hline $\mathrm{BHU} / \mathrm{HC}$ & 1 & - & - & - & - & 1 & 1 & - & - & 1 & 5 & - & - & 9 & 22.5 \\
\hline School pharmacy & - & - & 3 & - & 1 & - & - & - & - & 1 & - & & - & 5 & 12.5 \\
\hline Domicile & 1 & - & - & - & - & - & 1 & - & - & - & 1 & - & - & 3 & 7.5 \\
\hline LTI & - & - & - & - & - & - & 1 & - & - & - & - & - & - & 1 & 2.5 \\
\hline Patients' Association & - & - & - & - & - & - & - & 1 & - & - & - & & - & 1 & 2.5 \\
\hline More than one venue & - & 1 & - & - & - & - & 1 & - & - & - & - & 1 & - & 3 & 7.5 \\
\hline Total & 3 & 1 & 4 & 1 & 1 & 2 & 8 & 2 & 2 & 4 & 9 & 2 & 1 & 40 & 1000 \\
\hline$\%$ & 7.5 & 2.5 & 10.0 & 2.5 & 2.5 & 5.0 & 20.0 & 5.0 & 5.0 & 10.0 & 22.5 & 5.0 & 2.5 & 100.0 & 100.0 \\
\hline
\end{tabular}

$\mathrm{HS}=$ Hospital Services $/ \mathrm{BHU}=$ Basic Health Unit $/ \mathrm{HC}=$ Health Center $/$ LTI = Long-term Institution 
theses units, the work of pharmacists is more focused on the management of medicines rather than on the process surrounding their use, which may be related, among other things, to: a) the lack of practical training for the direct care of patients; b) insufficient number of pharmacists to engage in both clinical and managerial activities; c) interaction with members of the health care team focused on resolution of operational problems and not on solving clinical drug-related problems which requires technical expertise; d) lack of resources and time for knowledge update (Araújo, Freitas, 2006).

One place that has not been researched in Brazil but has been identified with studies conducted in the United States is the clinic environment. The pharmacist's employment as a free-lance professional, a trend that has become more and more commonplace in the United States, but is still incipient in Brazil. It is believed that, due to this fact, articles evaluating this professional's practice in those places have not been identified. However, two potentially important fields for research in Brazil have been established: domiciles in the "Programa de Saúde da Família (PSF / Family Health Program)" context, identified in one study only, and Farmácia Popular (Popular Pharmacy)2, which was not a focus of any of the studies retrieved. These fields are related to governmental programs, which have been increasing in the country, and also create promising environments for the development of care models focused on the use of medicines.

In terms of the locations where the field studies were carried out, São Paulo and Paraná together accounted for $42.5 \%$ of study locales (Table III). The state of Paraná showed broader diversification in the researched fields, followed by São Paulo and Santa Catarina.

In macroregional terms, the Southeast region was the location of only two of the studies on community pharmacy identified (Minas Gerais and São Paulo), versus five studies in the South region (four in Paraná and one in Santa Catarina). As reported by Castro and Correr (2007), according to the "Conselho Federal de Farmácia" (Pharmacy Federal Committee), there were 62.454 community pharmacies in 2004 in Brazil, 22.1\% of these belonged to pharmacists - the Southeast Region was the one with the

1-Family Health Program: a national strategy which aims to reorganize the health assistance model, carried out by means of the implementation of multiprofessional teams in basic health units. These teams are responsible for the follow-up of a specific number of families living in a pre-defined geographical area. The teams carry out health promotion actions, prevention, recovery, disease rehabilitation, and most frequent injuries, as well as health maintenance regarding the community in question.

2-Popular Pharmacy: Program created by the Health Ministry of Brazil in order to increase access of the population to essential medicines sold at lower prices than the usual trade price. largest number of pharmacist proprietors (34.7\%), and the State of Paraná the one with most pharmacist proprietors of pharmacies $(41.6 \%)$. The Southeast concentrates the largest number of community pharmacies in the country $(50.7 \%)$, followed by the South and the Northeast Regions, both with $18.5 \%$. The number of studies on this environment was expected to be higher in these regions. An explanation for this finding is that Brazilian pharmacies in general, whether belonging to pharmacists or otherwise, have a very strong commercial character and little potential for the performance of clinical services. Besides, due to the abovementioned reasons, the professionals working at the service would not be encouraged to conduct research in their practice (Vieira, 2007; Novaes, 2004; Farina, Romano-Lieber, 2009).

\section{The articles}

The representativeness of both the title and the abstract in relation to the full text was analysed. In $84.1 \%$ of the articles the title was representative. For abstracts, one article did not contain an abstract. In fifty-seven articles $(90.5 \%)$ the abstract was representative while in $5(7.9 \%)$ it was not representative of the complete text - these five are the same studies whose titles did not represent the texts. This finding could be related to the divergence in the concepts of pharmaceutical care and pharmaceutical assistance (Funchal-Witzel, 2008), which led to the identification of contents in the abstract and in the title that did not match the themes presented in the article.

Regarding the number of publications, only 3 articles dealing with pharmaceutical care in indexed journals before 2002 were retrieved. From 2002 publications appeared on an annual basis. However, only after 2006 (Figure 1) was a trend toward an increase in this production noted, with 9 articles being retrieved in 2006 (more than double the publications found in 2005), 12 in 2007, 13 in 2008, and 14 in 2009 (55\% more compared to 2006). Oshiro and Castro (2008) presented 1999 as marking the start of Brazilian production, and showed that this production started to increase from 2000. These findings may be due to the fact that the authors did not analyze only the articles published in indexed journals.

Pereira and Freitas (2008), in a survey conducted on December $31^{\text {st }}$ of 2007 , on the Medline database, found frequencies of publications ranging from 7,975 articles published in the United States to 9 in Argentina. In the survey, it was noted that the production related to pharmaceutical care was low in developing countries. Nevertheless, in Latin America, Brazil led the ranking for publications followed by Mexico, Chile and Argentina. 


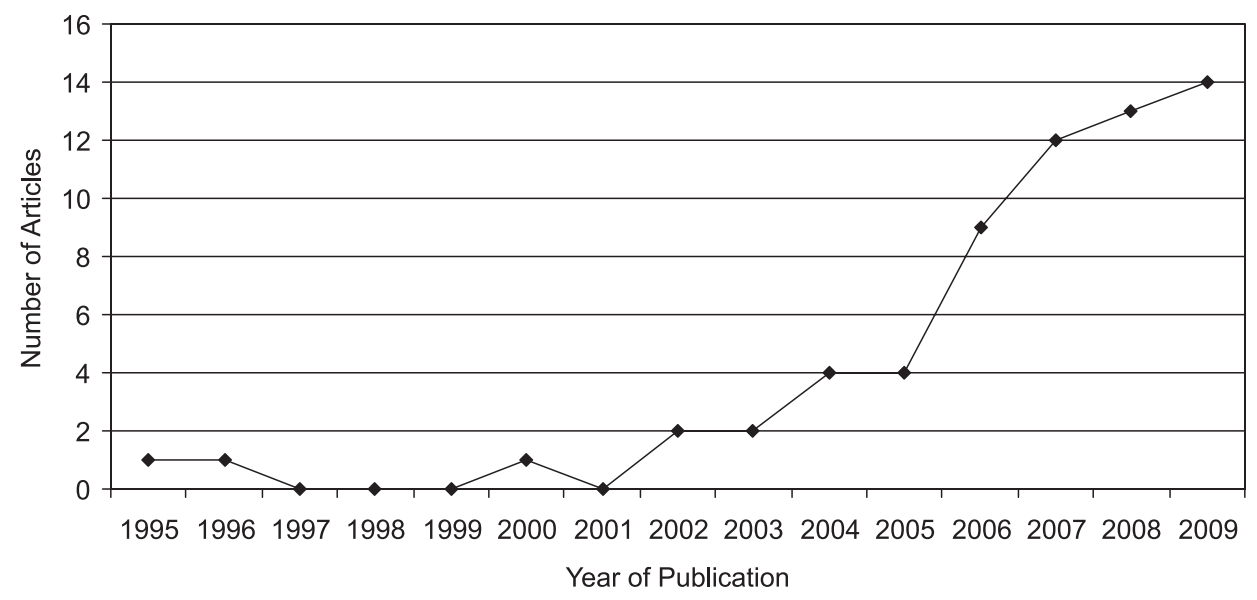

FIGURE 1 - Distribution of number of articles on pharmaceutical care published in indexed journals on databases by year of publication. Brazil, 1990 - 2009.

The cited authors attributed the low publication in Brazil versus countries in North America and Europe to the low importance this theme has in the country, apart from the publications of articles in non-indexed journals, which is probably due to methodological problems.

Rangel Mayoral, Luis Fernández and Liso Rúbio (2005), in a systematic review on the status of studies in biomedical journals on pharmaceutical care between 1999 and 2004, highlighted that the countries that are responsible for the majority of published studies on pharmaceutical care were: The United States, with $61 \%$, followed by Holland (8\%), Canada (6\%), Spain and Great Britain (both with $4 \%$ of the publications). Brazil was not listed in this study, which is probably due to the review period, the inclusion criteria established, and to the databases searched.

It is important to point out that in Brazil, the pharmaceutical care theme started to be discussed with deeper intensity in 2000, one decade after the formulation of the concept by Hepler and Strand. Thus, due to the fact that this is a recent theme, it has not yet been consolidated in the country as a compulsory assignment in the curricula of most of the pharmacy courses. More time is necessary for studies and experience on the theme to start taking shape. Nevertheless, Oshiro and Castro (2008) and Ferreira (2008) mention a trend toward an increase in the number of publications about the theme in Brazil. Ferreira (2008) reported a significant number of articles in the pharmaceutical care area that have been submitted for publication in the Revista Brasileira de Ciências Farmacêuticas (Brazilian Journal of Pharmaceutical Sciences), which reflects both the structuring of this area in the country and the trends in teaching based on the Brazilian new curriculum guidelines.

As to the type of article, according to the proposed classification by Curty and Boccato (2005), 65.1\% were considered to be Original, 20.6\% Updates, $7.9 \%$ Reviews, $4.8 \%$ communications, and $1.6 \%$ Report on Clinic Case. However, based on criteria of the journal publishers, these articles have been classified in a greater number of categories, with the main ones being $54.0 \%$ Originals and $14.3 \%$ Reviews, thus comprising $68.3 \%$ of the total. The remaining $31.7 \%$ were included in the Others categories unconventionally found in literature, such as pharmaceutical care in the world, pharmaceutical care, free themes, research report, information, notes, tools for the progress of pharmaceutical care, viewpoints or simple article (Figure 2).

By assessing the characteristics of the Latin American scientific journals, Castro, Ferreira and Vidili (1996) found some difficulties related to the "type of article" category, which were not always adequately explicit, accurate, clear or even related to the content of the published text. For instance, the journals often inform that an article is a review when, in fact, it technically corresponds to an update.

In order to assess the themes of the articles they were categorized by comprehensive groupings called theme domains. The prevailing theme domain was named "macrocomponents of professional practice", and the most often published subjects were: health education, dispensing, pharmaceutical attendance, pharmaceutical orientation, pharmacotherapeutic follow-up, and rational use of medicines. The least approached themes were: record of activities, measurement and evaluation of (clinical, economic and humanistic) pharmaceutical care results.

Regarding the studies involving the pharmacotherapeutic follow-up practice, 13 articles $(20.6 \%)$ involving this theme were found. Out of the 13 articles, 8 used the Dáder method, 2 employed a method developed 
Curty and Boccato Classification, 2005
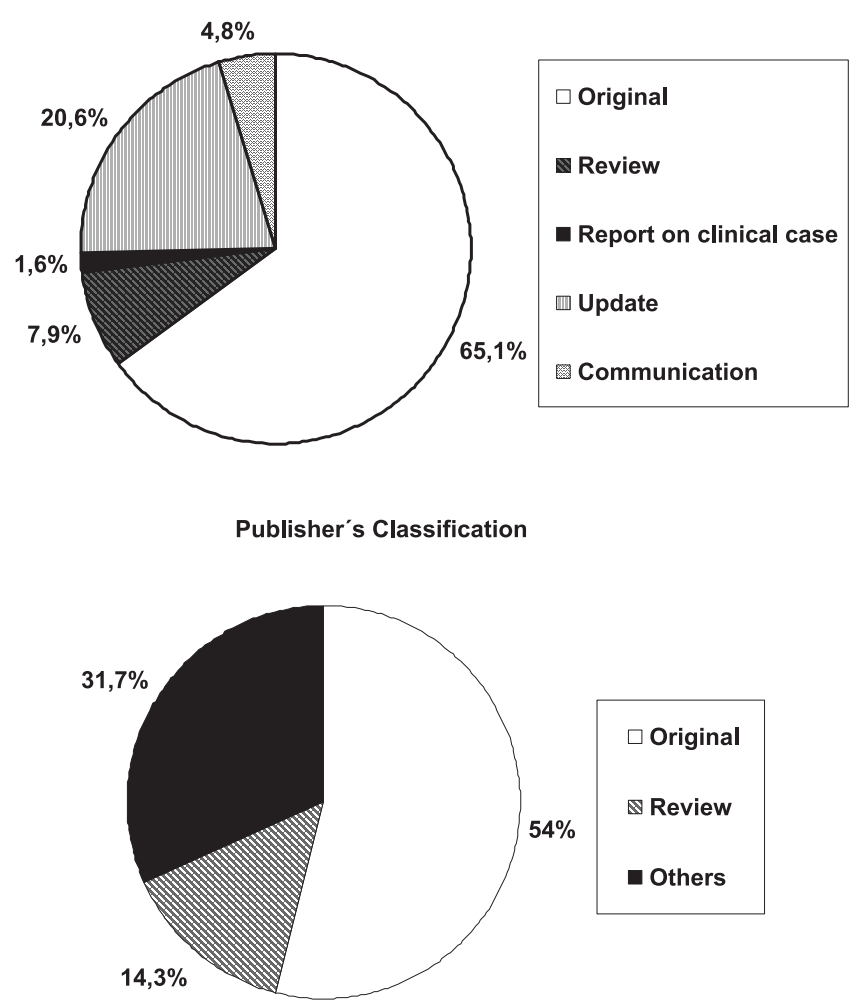

FIGURE 2 - Classification of articles on pharmaceutical care published in indexed journals on databases according to Curty and Boccato (2005) and according to publishers of journals. Brazil, 1990-2009.

by the author himself, and 3 had unidentifiable methods. The average follow-up time was 331.8 days, and the longest 730 days, while 120 days was the shortest.

Concerning the explicit aims of the articles, $61.9 \%$ had only one aim, $25.4 \%$ two, $6.3 \%$ three, $6.3 \%$ four aims.

Regarding the methodological options, in $31.7 \%$ of the articles a bibliographical design was adopted, in $28.6 \%$ qualitative, $23.8 \%$ intervention type, and $15.9 \%$ used an observational design study. These findings indicate the need for further understanding of the meaning of pharmaceutical care, and also make evident the intervention character implicit in this new professional practice.

With reference to the conclusion section, $61.9 \%$ corresponded to the article goal(s). In $23.8 \%$ the correspondence was partial, and in $14.3 \%$ there was no correspondence. Volpato and Freitas (2003) point out that the article wording, based on the conclusions and working backwards to the beginning, is a technique that allows the author to write the text already confident of the adequacy of the argument, grounded in valid goals and adequate methods, results and conclusions.

\section{Studied population}

In $39.7 \%$ of the assessed articles, the identification of the studied population was not a requirement for the object of study. For the remainder, the following research subjects were identified: patient, pharmacist, non-patient, individuals with special needs, non-pharmacist, pharmacy professional, health professional, and pharmacist student.

Regarding the articles that had the patient as the study subject, the researched age groups were: children, teenagers, young adults, adults and elderly. The most researched groups were elderly, adults and young adults, in this order. Most of the subjects were individuals with chronic diseases. The majority of the articles were on studies involving both sexes. Rangel Mayoral, Luis Fernández and Liso Rúbio (2005) reported that the most researched patient group in studies on pharmaceutical care was the elderly, and the most studied diseases were chronic degenerative diseases. Oshiro and Castro (2008) also reported that the chronic degenerative diseases were the most frequently addressed conditions in Brazilian publications - consistent with the findings of this work.

\section{FINAL CONSIDERATIONS}

In general, the Brazilian scientific production on pharmaceutical care published in indexed journals on databases from 1990 to 2009 showed the following main characteristics: modest in number considering the country's potential; predominantly published in journals related to the pharmaceutical area by authors affiliated with public universities, whose main geographical origins are the State of São Paulo and Paraná - corresponding mainly to descriptive studies. The most frequently researched fields were community pharmacies, hospital services and primary health care units; this kind of research is concentrated in the Southeast and South Regions of the country. Most of the articles were classified as original, with titles and abstracts representing the published content, had a single aim, and dealt with themes related to the macrocomponents of the professional practice, with bibliographical type studies prevailing. The academic output has been increasing in number, especially from 2006. There were studies involving pharmacotherapeutic follow-up that used different methodology with follow-up time averaging around one year. The population of studied patients comprised elderly, adults and young adults, patients with chronic degenerative diseases, and male and female individuals.

These results point to the importance of increasing the number and quality of publications, and of stimulating the conducting of both controlled and randomized 
experimental studies, which provide the best scientific evidence, as well as qualitative studies that contribute to a better understanding of the phenomena involved in the use of medicines in society. The increase in authorships connected with the service areas as well as the interaction between Brazilian and foreign authors, the latter with more cumulated experience about the theme, can also contribute toward reaching this goal.

The studies that involve primary data need to be broadened to include different settings, including little researched locales or venues with potential to yield data that allow a better understanding of users' needs regarding medicines, such as in domiciles and Farmácias Populares (Popular Pharmacies). There is a lack of publications regarding clinical case reports, as well as pharmacotherapeutic follow-up with in-depth details on the methodology used.

A lack of studies involving children, women and men (independently), teenagers, pregnant women, nursing women and individuals with special needs was noted. Future studies should take into consideration a number of more diversified clinical situations. The studies on elderly, adults and young adults can also be broadened. It is important to include subjects involved in the pharmaceutical care practice in the studies, such as pharmacists, physicians, health administrators, healthcare professionals in general, health area students, and caretakers, among others.

Despite the fact that the number of publications related to the pharmaceutical care area is still in its infancy, it is evident that academic output has been increasing, and there is potential for further growth in the country. In addition, it is evident that there is a vast field yet to be researched in areas and sectors already identified. It is hoped that as this practice continues to consolidate in the country, an increase in the number, scope and quality of studies occurs, so that scientific knowledge can contribute to the strengthening of the pharmacist's role in the health industry, and that this professional may gain recognition for their actions from other professionals in the health area, and also that their inclusion is translated into better quality in patient care.

\section{ACKNOWLEDGMENT}

The authors express their thanks to the Instituto Racine for the indirect financial support of the Master's Dissertation presented to the Public Health Post-Graduate Program of the Faculdade de Saúde Pública da Universidade de São Paulo (Public Health Faculty of the São Paulo University), which served as the basis of this article.

\section{REFERENCES}

ANDRÉS IGLÉSIAS, J.C.; ANDRÉS RODRÍGUEZ. N.F.; FORNÓS PÉREZ, J.A. La investigación en farmácia comunitaria en España: estudio bibliométrico. Pharm. Pract., v.5, n.1, p.21-30, 2007.

ARAÚJO, A.L.A.; FREITAS, O. Concepções do profissional farmacêutico sobre a assistência farmacêutica na unidade básica de saúde: dificuldades e elementos para a mudança. Rev. Bras. Ciênc. Farm., v.42, n.1, p.137-146, 20

BAENA PAREJO, M.I.; FAUS DÁDER, M.J.; MARINIGLÉSIAS, R.; ZARZUELO-ZURITA, A.; JIMÉNEZMARTÍN, J.; MARTINEZ-OLMOS, J. Problemas de salud relacionados con los medicamentos en un sevicio de urgencias hospitalario. Med. Clin. (Barc), v.124, n.7, p.250-255, 2005.

BOOTMAN, J.L.; DONALD, L.T.C.; HARRISON, L.; COX, E. The health care cost of drug-related morbidity and mortality in nursing facilities. Arch. Intern. Med., v.157, n.18, p.2089-2096, 1997.

BRASIL. Ministério da Saúde. Secretaria de Ciência, Tecnologia e Insumos Estratégicos. Seminário Internacional para a implementação da atenção farmacêutica no sistema único de saúde (SUS): material do facilitador. Brasília, 2006. Available at: $<$ http://portal.saude.gov.br/portal/arquivos/ pdf/MATERIAL_DO_FACILITADOR.pdf $>$. Accessed on: 22 jul. 2010.

CAMPOS VIEIRA, N.; BICAS ROCHA, K.; CALLEJA HERNÁNDEZ, M.A.; FAUS DÁDER, M.J. Seguimiento farmacoterapéutico em pacientes ingresados em el servicio de medicina interna del Hospital Infanta Margarida. Farm. Hosp., v.28, n.4, p.251-257, 2004.

CASTRO, M.S. DE; CORRER, C.J. Pharmaceutical care in community pharmacies: practice and research in Brazil. Ann. Pharmacother., v.41, n.9, p.1486-1493, 2007.

CASTRO, R.C.F.; FERREIRA, M.C.G.; VIDILI, A.L. Periódicos latino-americanos: avaliação das características formais e sua relação com a qualidade científica. Cienc. Inf., Brasília, v.25, n.3, dez. 1996. Available at: <http:// revistaibict BR/índex php/ciinf/article/view/459/418>. Accessed on: 6 jun. 2009. 
CIPOLLE, R.J.; STRAND, L.M.; MORLEY, P.C. El ejercicio de la atención farmacéutica. Madrid: McGraw-Hill/ Interamericana, 2000. 352 p.

COIMBRA JR, C.E.A. Produção científica em saúde pública e as bases bibliográficas internacionais. Cad. Saúde Pública., v.15, n.4, p.883-888, 1999.

CURTY, M.G.; BOCCATO, V.R.C. O artigo científico como forma de comunicação do conhecimento na área de ciências da informação. Perspect. Ciênc. Inf., v.10, n.1, p.94-107, 2005.

DALL'AGNOL, R.S.A.; ALBRING, D.V.; CASTRO, M.S. DE; HEINECK, I. Problemas relacionados com medicamentos em serviços de emergência de hospital universitário do Sul do Brasil. Estudo piloto. Acta Farm. Bonaer., v.23, n.4, p.540-545, 2004.

FARINA, S.S.; ROMANO-LIEBER, N.S. Atenção farmacêutica em farmácias e drogarias: existe um processo de mudança? Saúde Soc., v.18, n.1, p.7-18, 2009.

FAUS DÁDER, M.J.; MARTÍNEZ-MARTÍNEZ, F. La Atención Farmacéutica en farmacia comunitaria: evolución de conceptos, necesidades de formatión, modalidades y estrategias para su puesta en marcha. Pharm. Care Esp., v.1, n.1, p.52-61, 1999.

FERREIRA, E.I. Editorial. Rev. Bras. Ciênc. Farm., v.44. n.4, p.i-ii, 2008.

FUNCHAL-WITZEL, M.D.R. Aspectos conceituais e filosóficos da assistência farmacêutica, farmácia clínica e atenção farmacêutica. In: STORPIRTIS S.; MORI, A.L.P.M.;YOCHIY, A.; RIBEIRO, E.; PORTA. V. (Orgs.). Farmácia Clínica e Atenção farmacêutica. Rio de Janeiro: Guanabara Koogan, 2008. p.336-348.

GIL, A.C. Como elaborar projetos de pesquisa. 3. ed. São Paulo: Atlas, 1995.159 p.

HEPLER, C.D.; GRAIGER-ROUSSEAUX, T.J. Pharmaceutical care versus traditional drug treatment: Is there a difference? Drugs, v.49, n.1, p.1-10,1995.

HEPLER, C.D.; STRAND, L.M. Opportunities and responsibilities in pharmaceutical care. Am. J. Hosp. Pharm., v.47, n.3, p.533-543, 1990.
MACHADO, M.; BAJCAR. J.; GUZZO, G.C.; ENARSON, T.R. Sensitivity of patient outcomes to pharmacyst intervencions. Part II: systematic review and meta-analysis in hypertension management. Ann. Pharmacother., v.41, n.11, p.1770-1781, 2007.

MAGARINOS-TORRES, R.; OSÓRIO-DE-CASTRO, C.G.S.; PEPE, V.L.E. Atividades de farmácia hospitalar brasileira para com pacientes hospitalizados uma revisão da literatura. Ciênc. Saúde Coletiva, v.12, n.4, p.973-984, 2007.

MARTINÉZ OLMOS, J.; BAENA PAREJO, M.I. La atención farmacéutica, requisito para conseguir una atención sanitaria de calidad y basada en la evidencia científica. Ars. Pharm., v.42, n.1, p.39-52, 2001.

MARTINÉZ OLMOS, J.; BAENA PAREJO, M.I. La atención farmacéutica como método para mejorar la salud de los pacientes y la cordinación entre los profesionales médicos y farmacéuticos (contestatión a Henrique Costas Lombardía). Pharm. Care Esp., v.3, n.2, p.135-139, 2001.

MUGNAINE, R.; JANNUZZI, P.; QUONIAN, L. Indicadores bibliométricos da produção científica brasileira: uma análise a partir da base Pascal. Ciência da Informação, Brasília, v.33, n.2, 2004. Available at: < http://quoniam.univ-tln. $\mathrm{fr} / \mathrm{pdf} /$ Articles/2004/ciencia_da_informacao_2004.pdf $>$. Accessed on: 22 jul. 2010.

NARVAI, P.C.; ALMEIDA, E.S. O sistema de saúde e as políticas de saúde na produção científica odontológica brasileira no período de 1986-1993. Cad. Saúde Pública, v.14, n.3, p.513-521, 1998 .

NARVAI, P.C.; FRAZÃO, P. Práticas de saúde pública. In: ROCHA, A.R.; CESAR, C.L.G. (Orgs.). Saúde Pública: bases conceituais. São Paulo: Atheneu, 2008. p.269-295.

NOVAES, H.M.D. Pesquisa em, sobre e para os serviços de saúde: panorama internacional e questões para a pesquisa em saúde no Brasil. Cad. Saúde Pública, v.20, suppl.2, p.147-157, 2004.

ORGANIZAÇÃO PAN-AMERICANA DA SAÚDE. Consenso Brasileiro de Atenção Farmacêutica: proposta. Brasília, 2002. 23 p. 
ORGANIZAÇÃO PAN-AMERICANA DA SAÚDE; CONSELHO FEDERAL DE FARMÁCIA. O papel do farmacêutico no sistema de atenção à saúde. Brasília, 2004. Available at: < http://www.opas.org.br/medicamentos/site/ Uploading/HSE_PFS_BPF_1004:pdf.>. Accessed on: 22 jul. 2010.

OSHIRO, M.L.; CASTRO, L.L.C. Atenção farmacêutica: revisão bibliográfica da produção brasileira de 1999 a 2005. In: STORPIRTIS, S.; MORI, A.L.P.M.; YOCHIY, A.; RIBEIRO, E.; PORTA, V. (Orgs.). Farmácia clínica e atenção farmacêutica. Rio de Janeiro: Guanabara Koogan, 2008. p.411-429.

PENNA, R.P. Pharmaceutical care: pharmacy's mission for the 1990s. Am. J. Hosp. Pharm., v.47, n.3, p.543-549, 1990.

PEREIRA, L.R.L.; FREITAS, O. A evolução da atenção farmacêutica e a perspectiva para o Brasil. Rev. Bras. Ciênc. Farm., v.44, n.4, p.601-612, 2008.

RANGEL MAYORAL, J.F.; LUIS FERNÁNDEZ, J.; LISO RÚBIO, F.J. Estado actual de la investigación en atención farmacéutica. Farm. Hosp., v.29, n.5, p.335-342, 2005.
SILVA CASTRO, M.M.; CALLEJA HERNÁNDEZ, M.A.; TUNEU VALLS, L.; FUENTES CAPARRÓS, B.; GUTIÉRREZ SÁINZ, J.; FAUS DÁDER, M.J. Seguimiento del tratamiento farmacológico en pacientes ingresados en un servicio de cirugía. Farm. Hosp., v.28, n.3, p.154-169, 2004.

SHOEMAKER, S.J.; OLIVEIRA, D.R. Understanding the meaning of medications for pacients: the medication experience. Pharm. World Sci., v.30, n.1, p.86-91, 2008.

TUNEU VALLS, L.; GARCÍA-PELÁEZ, M.; LÓPEZ SÁNCHEZ, S.; SERRA SOLER, G.; ALBAARANDA, G.; IRALA INDART, C. D. E; RAMOS, J.; TOMÁS SANS, R.; BRAVO JOSÉ, P.; BONAL DE FALGÁS, J. Problemas relacionados con los medicamentos en pacientes que visitan un servicio de urgencias. Pharm. Care Esp., v.2, n.3, p.177$192,2000$.

VIEIRA, F.S. Possibilidades de contribuição do farmacêutico para a promoção da saúde. Ciênc. Saúde Coletiva, v.12, n.1, p.213-220, 2007.

VOLPATO, G.L.; FREITAS, E.G. Desafios na publicação científica. Pesq. Odontol. Bras., v.17, suppl.1, p.49-56, 2003.

Received for publication on $14^{\text {th }}$ October 2010 Accepted for publication on $18^{\text {th }}$ January 2011 